
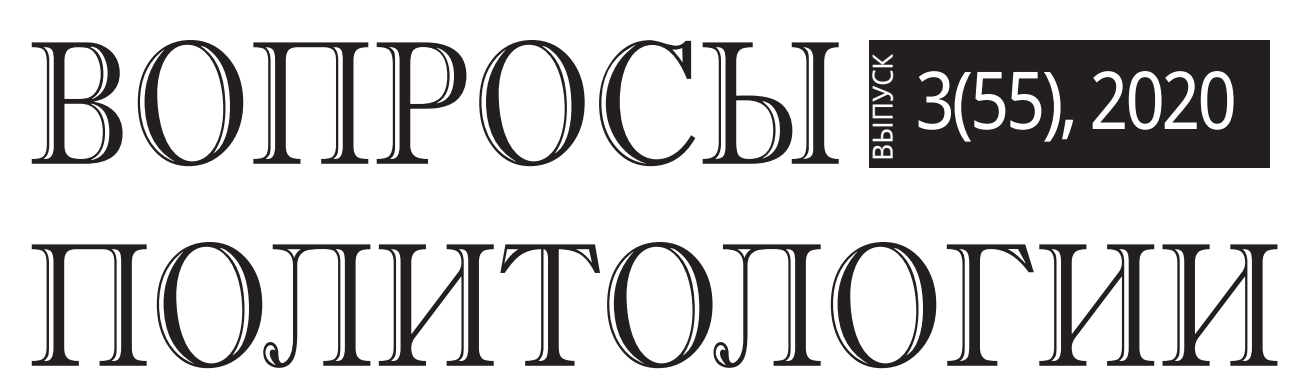

Научный журнал

Журнал «Вопросы политологии» включен

в Перечень рецензируемых научных изданий

BAK Министерства образования и науки РФ по политическим наукам, в которых должны быть опубликованы основные научные результаты на соискание ученой степени кандидата наук,

на соискание ученой степени доктора наук

Журнал включен в Перечень научных изданий рекомендованных ВАК Республики Узбекистан для публикации основных научных результатов диссертаций по политическим и философским наукам 
Председатель Редакционного Совета - ПЛАТОНОВ В.М.,

К.ю.н., заведующий кафедрой политического анализа и управления РУДН, Председатель Московской городской Думы (1994-2014 гг.)

\section{Редакционный Совет}

\section{АСТВАЦАТУРОВА}

Майя Арташесовна

БОЖАНОВ

Владимир Александрович

ВЕДРИН

Оливье

ДОНАЙ

Лукаш

ЖИЛЬЦОВ

Сергей Сергеевич

ИРХИН

Юрий Васильевич

\section{КАРАДЖЕ}

Татьяна Васильевна

КЕТЦЯН

Григор Ваникович

\section{КОВАЛЕНКО}

Валерий Иванович

КРИВОКАПИЧ

Борис

МЕДВЕДЕВ

Николай Павлович

МИХАЙЛОВ

Вячеслав Александрович

\section{НАСИМОВА}

Гульнара Орленбаевна

\section{НИСНЕВИЧ}

Юлий Анатольевич

Шукритдин Ильясович

ПЛЯЙС

Яков Андреевич

ПРЯХИН

Владимир Федорович

ПУСЬКО

Виталий Станиславович

\section{ХОПЁРСКАЯ}

Лариса Львовна

\section{ПАХРУТДИНОВ}

д.п.н., профессор, директор Центра этнополитических исследований, профессор кафедры креативноинновационного управления и права Пятигорского государственного университета, координатор Сети этнологического мониторинга и раннего предупреждения конфликтов в СКФО (Россия, г. Пятигорск)

д.и.н., профессор, зав. кафедрой мировой и отечественной культуры Белорусского Национального технического университета (Белоруссия, г. Минск)

профессор, главный редактор русской версии французского журнала «Национальная оборона» (Revue Défense Nationale), спикер Европейской комиссии, редактор франко-германского журнала по вопросам внешней политики «European Union Foreign Affairs Journal» и ректор «Континентального университета в Киеве» (Франция, г. Париж)

Д.п.н., профессор факультета политологии и журналистики Департамента международных отношений Университета им. Адама Мицкевича в Познани (Польша, г. Познань)

д.п.н., заведующий кафедрой политологии и политической философии Дипломатической академии МИД РФ (Россия, г. Москва)

д.ф.н., профессор кафедры политологии и политического управления РАНХ и ГС при Президенте РФ (Россия, г. Москва)

д.ф.н., заведующая кафедрой политологии и социологии МПГУ (Россия, г. Москва)

к.П.Н., заместитель Главного редактора журнала, Председатель Попечительского Совета научного журнала «Вопросы политологии» (Россия, г. Москва) д.ф.н., зав. кафедрой российской политики МГУ им. М.В. Ломоносова (Россия, г. Москва) д.ю.н., профессор факультета бизнеса и права Унион Никола Тесла университета (Сербия, Белград)

д.п.н., профессор кафедры анализа и управления Российского университета дружбы народов, главный редактор журнала (Россия, г. Москва) д.и.н., зав. кафедрой национальных и федеративных отношений РАНХ и ГС при Президенте РФ (Россия, г. Москва)

д.п.н., профессор, зав. кафедрой политологии факультета философии и политологии Казахского Национального университета им. Аль-Фараби (Казахстан, г. Алматы) д.п.н., профессор Национального исследовательского университета «Высшая школа экономики» (Россия, г. Москва)

д.п.н., профессор, заведующий кафедрой основы духовности Института переподготовки и повышения квалификации руководителей и специалистов системы народного образования имени А. Авлони (Узбекистан, г. Ташкент)

д.и.н., д.п.н., профессор Финансового университета при Правительстве РФ (Россия, г. Москва)

д.п.н., профессор кафедры зарубежного регионоведения и внешней политики РГГУ (Россия, г. Москва)

д.ф.н., профессор кафедры гуманитарных дисциплин ВА РВСН им. Петра Великого (Россия, г. Москва)

д.п.н., профессор кафедры международных отношений Киргизско-Российского славянского университета, (Киргизия, г. Бишкек)

\section{Редакщионная коллегия}

Главный редактор - МЕДВЕДЕВ Н.П., д.П.н., профессор

Абрамова О.Д. (д.п.н.)

Насимова Г.О. (д.п.н.)

Кетцян Г.В. (к.п.н. - зам. гл. редактора)
ISSN 2225-8922

ЖУРНАЛ ВКЛЮЧЕН В ПЕРЕЧЕНЬ ВАК РФ

\section{УЧРЕЖДЕН}

ООО «Издательство «Наука сегодня»

Журнал зарегистрирован

Федеральной службой по надзору в сфере массовых коммуникаций, связи и охраны культурного наследия

\section{Рег. № ПИ № ФС77-46176} от 12 августа 2011 г.

Журнал издается ежемесячно

Журнал включен в базу РИНЦ (Российский индекс научного цитирования)

Включен в каталог Ulrich's Periodicals Directory

Пятилетний импакт-фактор: 1,489.

Адрес редакции: 115598 , г. Москва, ул. Загорьевская, д. 10, корп. 4, цокольный этаж, помещение I, комната 7-1, офис 4 Тел.: (910) 463-53-42

Интернет-ресурс: www.voprospolitolog.ru E-mail: voprospolitolog@yandex.ru

Мнение авторов может не совпадать с мнением редакции. При перепечатке ссылка на журнал обязательна.

Научные статьи, публикуемые в журнале подлежат обязательному рецензированию.

Ответственный редактор Шкурина С.С.

Перевод

Чернышова Е.В.

Компьютерная верстка Анциферова А.С.

Подписано в печать 25.03.2020

Формат 60×84/8. Объем 24,3.

Печать офсетная.

Тираж - 1000 экз.

(1-й завод - 500 экз.) Заказ № 50376.

Отпечатано в типографии PrintUP 117105 , г. Москва, Нагорный проезд, 12, корп. 1 Тел.: +7 (495) 925-00-06 
ISSN 2225-8922 (print)

12 выпусков в год и

4 выпуска в год переводной (англ.) версии

Языки: русский, английский

http://voprospolitolog

Входит в перечень рецензируемых научных изданий ВАК РФ

Включен в каталог периодических изданий Ульрих

(Ulrich's Periodicals Directory: http://www.ulrichsweb.com)

Материалы журнала размещаются на платформе РИНЦ

Российской научной электронной библиотеки, Electronic Journals Library Cyberleninka

Подписной индекс издания в каталоге агентства Роспечать 70035

\section{Цели и тематика}

Журнал ВОПРОСЫ ПОЛИТОЛОГИИ - периодическое международное рецензируемое научное издание в области политических исследований. Журнал является международным как по составу редакционного совета и редколлегии, так и по авторам и тематике публикаций.

Научный журнал издается с 2011 года в издательстве «Наука сегодня». С 2016 года издается переводная (англ.) версия журнала. С момента своего создания, журнал ориентировался на высокие научные и этические стандарта и сегодня является одним из ведущих политологических журналов России.

Цель журнала - способствовать научному обмену и сотрудничеству между российскими и зарубежными политологами.

Журнал предназначен для публикации результатов фундаментальных и прикладных научных исследований. Тематическая направленность журнала отражается в следующих постоянных рубриках: «История и философия политики», «Политические институты, процессы и технологии», «Политическая регионалистика и этнополитика», «Политическая культура и идеологии», «Политические проблемы международных отношений и глобализации».

Формат публикаций: научные статьи, обзорные научные материалы, материалы круглых столов, научные рецензии, научные сообщения, посвященные исследовательским проблемам в сфере политики и политологии.

В своей деятельности редакционный совет и редколлегия журнала руководствуется принципами, определяемыми ВАК России для научных журналов, в том числе: наличие института рецензирования для экспертной оценки качества научных статей; информационная открытость издания; наличие и соблюдение правил и этических стандартов представления рукописей авторами

Целевой аудиторией журнала являются российские и зарубежные специалисты-политологи, а также аспиранты и магистры, обучающиеся по направлениям политология, государственное и муниципальное управление и международные отношения.

Журнал строго придерживается международных стандартов публикационной этики, обозначенных в документе СОРЕ (Committee on Publication Ethics) http://publicationethics.org

Полные сведения о журнале и его редакционной политике, требования о подготовке и публикации статей, архив (выпуски c 2011 года) и дополнительная информация размещена на сайте: http://voprospolitolog.ru

Электронный адрес: voprospolitolog@yandex.ru

ISSN 2225-8922 (print)

12 issues a year plus 4 issues a year of the translated (eng.) version Languages: Russian and English http://voprospolitolog

Included in the list of peer-reviewed scientific publications of the Higher Attestation Commission of the Russian Federation Included in the Ulrich's Periodicals Directory Materials of the journal are placed on the RSCI platform of the Russian scientific electronic library - Electronic Journals Library Cyberleninka Subscription index of the journal in the Rospechat Agency catalogue is: 70035

\section{Objectives and themes}

Academic journal "Political Science Issues" is an international peer-reviewed scientific periodical in the field of political studies. The journal has an international character because of the composition of its Editorial Board, its editors, its contributing authors and topics of its publications.

The scientific journal is published since 2011 at the "Publishing House "Science Today". Translated (eng.) version of the journal is published since 2016. Since its inception, the journal was guided by high scientific and ethical standards and today it is one of the leading political science journals in Russia.

The purpose of the journal is to promote scientific exchange and cooperation between Russian and foreign political scientists.

The journal is intended for the publication of the results of fundamental and applied scientific research. Thematic focus of the journal is reflected in the following permanent headings: "History and philosophy of politics," "Political institutions, processes and technologies," "Political regionalism and ethno-politics," "Political culture and ideologies," "Political problems of international relations and globalization."

Format of publications: scientific articles, reviews, scientific materials, materials of round tables, scientific reviews, scientific reports devoted to research problems in the field of politics and political science.

The Editorial Board and the editors of the journal in their activities are guided by the principles defined by VAK of Russia for scientific journals, including: presence of the institute of peer review for the expert quality assessment of scientific articles; information openness of the publications; availability and compliance with the rules and ethical standards for the submission of manuscripts by the authors.

The target audience of the journal is Russian and foreign specialists-political scientists, as well as graduate students and masters in the fields of political science, state and municipal management and international relations.

The journal strictly adheres to the international publishing standards and publication ethics identified in the COPE (Committee on Publication Ethics) document. http://publicationethics.org.

Full details of the journal and its editorial policy, requirements to the preparation and publication of articles, archive (issues since 2011) and additional information are available on the website: http://voprospolitolog.ru

E-mail address: voprospolitolog@yandex.ru 


\section{ТЕОРИЯ, ФИЛОСОФИЯ И ИСТОРИЯ ПОЛИТИКИ}

Гаджиев К.C. Проект «Один пояс, один путь»

в геополитическом измерении ....

Николенко А.А., Тушков А.А. К вопросу о методологических

основах исследования подходов к проблемам локальных цивилизаций.

Azапов П.В. Религия в творчестве Эриха Фромма:

социально-психологические аспекты проблемы

\section{ПОЛИТИЧЕСКИЕ ИНСТИТУТЫ, ПРОЦЕССЫ И ТЕХНОЛОГИИ}

Румянцев О.Г. О некоторых политологических аспектах конституционной реформы 2020 года в Российской Федерации

Пустовойт Ю.А., Антонов К.А. «А и Б сидели на трубе»:

конструирование протестной идентичности в ходе «тарифной войны»

в Новосибирске (2016-2017 гг.)

Артемьев A.A., Пыхтин С.H. Новые медиа как инструмент влияния на политические процессы в современном российском обществе

Бакшеева А.Р., Гусарская Т.А., Беляева В.П. Особенности реализации государственной антикоррупционной политики в современной России: механизм государственного контроля в контрактной системе государственных закупок

Булах Е.В., Князева А.P., Цой В.Г. Трайбализм

на Дальнем Востоке России: остаточные проявления

регионального колорита или новые формы.

Воронина Н.А. Политика интеграции мигрантов и беженцев в странах ЕС ...... 782

Kрюкова $\boldsymbol{E} . \boldsymbol{B}$. Роль общественно-политических организаций

в урегулировании политических конфликтов: возможности и перспективы

Галкина Г.M. Образовательная политика в программах

политических партий (на примере Коммунистической партии

Российской Федерации и Справедливой России)

Ворончихина Д.Н. Роль Ассоциации «Арктические муниципалитеты»

при осуществлении государственной политики в арктической зоне

Российской Федерации......

МЕЖДУНАРОДНЫЕ ОТНОШЕНИЯ И МИРОВАЯ ПОЛИТИКА

Михайленко А.Н. Как раскрывать

внешнеполитический потенциал России?

Mypaвbx A.И., Никитенко E.Г. Запад против обнуления

президентских сроков в России

Сергеева С.Л., Гапонов П.В. Практика реализации проектов

на основе муниципально-частного партнерства в Российской Федерации

и странах Европейского Союза: сравнительный анализ 
Tетерюк A.C. Анализ распределения результатов выборов в парламент Финляндии в ходе четырех электоральных циклов

Хлопов О.А. Энергетическая безопасность

Европейского союза: между Россией и США

Костоев 3.И., Арапханова Л.Я. Северный Кавказ

в контексте международной политики

Kaратуева $\boldsymbol{E} . \boldsymbol{H}$. Проблемы и предотвращение

продовольственного терроризма

Жамбаева У.Б. Буддизм Тибета в политическом контексте династии Юань.

Султанова A.P. Концептуальные подходы к формированию

национальной модели развития гражданского общества в Узбекистане

Афонин А.Д. Выход стран Балтии

из энергокольца БРЭЛЛ: причины и следствия

Петрова К.С. Профилактика исламского экстремизма

и терроризма в Республике Татарстан

Балданова P.A. Совместный университет «МГУ-ППИ в Шэньчжэне»

как часть миграционной политики КНР

Адум Кагер, Шуленина Н.В. Китай и Африканский союз:

проблемы и перспективы

Джавад O.B. Языковые аспекты обеспечения

социетальной безопасности в странах Западной Европы

Юлдашева М.К. Критерий информационной безопасности

в процессах межкультурной интеграции

Усмонов С. Общечеловеческие принципы

и особенность национальной идеи (идеологии) в Узбекистане

Еремина Я.В. Информационные технологии

как инструмент «мягкой силы»

Шолкова М.А. Безопасность и ее обеспечение на различных геополитических уровнях

Гао Дай Антикоррупционное противодействие в Китае:

история и современность

Чэнь Ханьчжи Развитие системы госслужбы КНР

как механизм формирования политических элит

Агоннуде Бидолей Вианней Фредди ЮАР и ООН:

аспекты взаимодействия.

Олувакайоде Олумиде Эммануэль, Мугаби Брайан, Джу Орлинду

Ключевые проблемы Африки/The Plagues of Africa

Чэн Го, Буторов А.С., Инь Цюнь Политический анализ

китайско-американской торговой войны и ее последствий/

The Political Analysis of the Sino-U.S. Trade War and Implications 
Ванграуа Садиа Рита Сониа, Егези Блессинг Чиманпа Отношения между Буркина-Фасо и Тайванем в период с 2000 года по 2018 год 1013

Лученков И.Р. Процессы политической интеграции в странах

Большого Ближнего Востока в рамках панарабистской концепции периода 1945-1990 гг..

\section{РАЗМЫШЛЕНИЯ НАД ПРОЧИТАННЫМ}

Слизовский Д.Е., Медведев Н.П. Послесловие к статье Румянцева О.Г. «О некоторых политологических аспектах конституционной реформы 2020 года в Российской Федерации» 1029

НАШИ АВТОРЫ 1038

ТРЕБОВАНИЯ К ОФОРМЛЕНИЮ РУКОПИСЕЙ 1047 
С.Л. СЕРГЕЕВА

кандидат политических наук,

дочент кафедры политологии и политического управления

Школы политических исследований

Института общественных наук

Российской академии народного хозяйства и государственной службь при Президенте РФ, Россия, г. Москва

П.В. ГАПОНОВ

соискатель кафедры политологии и политического управления Школь политических исследований

Института общественных наук Российской академии народного хозяйства и государственной службь при Президенте РФ, Россия, г. Москва

\section{ПРАКТИКА РЕАЛИЗАЦИИ ПРОЕКТОВ НА ОСНОВЕ МУНИЦИПАЛЬНО-ЧАСТНОГО ПАРТНЕРСТВА В РОССИЙСКОЙ ФЕДЕРАЦИИ И СТРАНАХ ЕВРОПЕЙСКОГО СОЮЗА: СРАВНИТЕЛЬНЫЙ АНАЛИЗ}

Развитие муниципально-частного партнерства (МЧП) пережило свое «второе рождение» после 2015 года, когда в соответствующее федеральное законодательство были внесены существенные изменения. В статье анализируются ключевые проблемы в процессе реализации проектов муниципально-частного партнерства (МЧП), которые возникли после вышеописанных изменений. Законодательные изменения позволили начать новый этап как во взаимоотношениях муниципальной власти, так и органов местного самоуправления с частным бизнесом. Однако необходимо признать, что темпы развития МЧП в России, с учетом огромной и постоянно растущей долговой нагрузки на муниципальные образования, остаются достаточно скромными. С учетом того факта, что текущая международно-политическая ситуачия не позволяет надеяться на какой-либо существенный объем иностранных инвестииий в региональную российскую экономику, представляет необходимым дальнейшее совершенствование механизмов партнерства государственных органов власти и частно- 
го сектора с иелью как повыпения уровня экономического развития, так и улучшения непосредственной средь обитания большинства городских и сельских жителей, в особенности за пределами более финансово и экономически успешных мегаполисов. Исходя из этого, представляется важным проанализировать опьт развития механизмов МЧП в формате Европейского союза, который обладает историческим опьтом развития в данной сфере. В данной статье анализируются ключевые механизмы, которые используют страны ЕС для более эффективного взаимодействия и развития совместных инфраструктурных и других сочиально-значимых проектов, а также управленческие принципы, на которых организуются подобные проектыл. Представляется, что часть таких инструментов, в особенности методики со-финансирования, принципа «funding gap», то есть учета и финансирования «кассовых разрывов», а также внедрения независимого арбитража в процессе реализации совместных проектов, являются крайне актуальными для российского опьта реализации МЧП и должны быть тщзательно проанализировань с иелью последующей адаптацчи и внедрения в российскую экономическую, юридическую и политическую практику.

Ключевые слова: муниципально-частное партнерство, МЧП, государственно-частное партнерство, ГЧП, местное самоуправление, европейская хартия самоуправления, Cohesion Program Regulation, public-private partnership, PPP, funding gap.

Муниципально-частное партнерство - в российской научной литературе также часто встречается терминология «государственно-частное партнерство» - это один из наиболее часто используемых механизмов, применяемых для привлечения частных инвестиций в экономику малых форм местного самоуправления различных европейских стран. В Российской Федерации, в силу целого ряда причин, анализ которых требует написания отдельной (и не одной) аналитической работы, технология муниципального-частного партнерства долгое время не функционировала полноценно. Только после внесения важных изменений в Федеральный закон «О государственно-частном партнерстве, муниципально-частном партнерстве в Российской Федерации и внесении изменений в отдельные законодательные акты Российской Федерации» от 13.07.2015 года, принципы муниципально-частного партнерства стали постепенно внедряться в экономическую, юридическую и управленческую практику различных муниципальных образований России [12].

Как представляется, обосновывать особую важность внедрения механизма муниципально-частного партнерства (здесь и далее - МЧП) не представляется необходимым ввиду ее явной актуальности - на сегодняшний день абсолютное большинство местных муниципальных образований, за исключением городов федерального значения и городов - центров феде- 
ральных округов, находятся в крайне сложной финансово-экономической ситуации, которая характеризуется в первую очередь, крайне низкой долей собственных финансовых средств, имеющихся в распоряжении самого муниципалитета, во-вторых, как следствие этого - высокой закредитованностью, и, в-третьих, как показывает практика, долговая нагрузка большинства муниципальных образований демонстрирует тенденцию к мало контролируемому росту [5. С. 2-33]. В этих условиях привлечение инвестиций из частного бизнеса внутри самой России представляется в качестве одного из главных «драйверов роста» экономики российских муниципалитетов, особенно небольших и малоизвестных за границами собственных федеральных округов, что делает малореальным на сегодняшний день привлечение каких-либо серьезных иностранных инвестиций.

Примечательно, что хронологическим «родоначальником» новой версии закона об МЧП в России стал город Улан-Удэ. Местные, локальные положения о муниципально-частном партнерстве и его функционировании были внесены в Устав муниципального образования города Улан-Удэ решением городского Совета депутатов еще в 2007 году [11].

Здесь сразу стоит отметить, что в наибольшей степени в России на данный момент развито участие частного сектора в том, что в государственных отчетах называется «культурно-досуговая деятельность». Как правило, частные компании более-менее охотно участвуют в проведении тех или иных фестивалей или городских праздников, естественным образом используя гарантированно большое стечение людей как субъектов собственной рекламной акции или компании, что в любом случае как минимум повысит узнаваемость бренда компании или ее репутацию.

Во всех остальных сферах, особенно таких стратегически важных (и более важных для населения, чем фестивальная деятельность) как тепло- и водоснабжение, а также предоставление концессий на право строительства и последующей коммерческой эксплуатации дорог, присутствие частного сектора как правило, весьма невелико, за исключением такого сомнительного с точки зрения полезности для городского хозяйства и транспорта вида деятельности как получение разрешений на частные маршрутные перевозки. Без сомнения, в условиях полного отсутствия какого-либо транспорта, система относительно отлаженных маршрутных перевозок воспринимается как благо для населения, однако на практике это приводит к возрастанию коррупционных рисков в сфере выдачи лицензии на пассажирские перевозки. Более того, впоследствии активное развитие такого рода транспорта может приводить к явной и системной передаче приоритета развития местного транспорта от муниципального (троллейбусы, муниципальные автобусы, трамваи) к частному, как правило, низкокачественному, маршрутному. В таких случаях приводятся аргументы в дешевизне, доступности и простоте организации таких перевозок, что в свою очередь приводит к увеличению 
дорожно-транспортных происшествий, неэффективному прокладыванию сети маршрутов, которая часто дублирует сама себя, но обслуживается при этом разными частными предпринимателями, каждый из которых ставит понятной целью только личный коммерческий интерес, а также постепенной дезорганизации муниципальной транспортной системы в целом и последующей ее деградации, и ликвидации [7. С. 160-166].

Помимо этого, большое влияние оказывает и локально-политическая ситуация в регионе - как правило, большинство проектов, реализуемых в формате МЧП - долгосрочные, и в случае смены руководства муниципалитета в процессе реализации договора, нет никаких серьезных гарантий того, что реализация проекта не будет свернута или существенным образом пересмотрена, что в свою очередь также связано с целым рядом коррупционных рисков. При этом, в ФЗ № 224 прямо указано, что длительность договора о МЧП не может быть менее трех лет подряд.

Наконец, существует комплексная правовая проблема, которая также обуславливает сложность реализации проектов на основе МЧП в России это нечеткость и обтекаемость формулировок в российском законодательстве, в особенности в федеральной его части. Так, Федеральный закон № 224 «О государственно-частном партнерстве, муниципально-частном партнерстве в Российской Федерации» описывает большое количество форм реализации МЧП в принципе - это собственно государственно-частное или муниципально-частное партнерство, а также публично-частное партнерство, концессию, инвестиционный договор, участие в капитале и целую массу слабо описанных иных форм, как например залог муниципального имущества, долгосрочная аренда этого имущества.

Вместе в тем, в настоящее время происходит трансформация российского законодательства в рамках функционирования органов местного самоуправления РФ. Центр местного самоуправления Института управления и регионального развития РАНХиГС при Президенте РФ подготовил очередной обзор изменений законодательства за период с 01 декабря 2019 года по 15 января 2020 года. Изменения были внесены в Федеральный закон от 27.12.2019 № 485-Ф3 «О внесении изменений в Федеральный закон «О государственных и муниципальных унитарных предприятиях» и Федеральный закон «О защите конкуренции» и иные правовые акты РФ - 29 федеральных законов, Постановлений Правительства РФ, Приказов Минюста России, Приказов Росстата РФ и т.д.

Основные темы выпуска № 1 (177):

Подписан Федеральный закон о запрете создания и функционирования унитарных предприятий на конкурентных рынках;

Руководить штабами территориальной обороны вместо глав муниципальных образований будут должностные лица местного самоуправления, возглавляющие местную администрацию; 
Подписан Федеральный закон, направленный на повышение «прозрачности» госзакупок в рамках контрактной системы;

Подписан закон об «электронных трудовых книжках»;

Временно исполняющие обязанности глав регионов получили право назначать представителей в Совет Федерации;

С 1 января 2020 года устанавливается порядок медицинского освидетельствования лиц, поступающих на службу в ФССП России на наличие или отсутствие у них заболеваний, препятствующих поступлению на службу в органы принудительного исполнения;

Уточнены полномочия Казначейством России по осуществлению контроля в финансово-бюджетной сфере;

Уточнены правила субсидируемого кредитования производства высокотехнологичной продукции гражданского и двойного назначения организациями оборонно-промышленного комплекса;

С 1 января 2020 года госзаказчики будут обязаны проводить обязательное общественное обсуждение госзакупок по новым правилам;

Скорректировано содержание правовых актов, устанавливающих порядок предоставления грантов в форме субсидий;

Росстатом утверждена обновленная статистическая форма N 1-администрация, по которой подаются сведения о муниципальных образованиях;

Минфином России даны рекомендации по применению КБК в 2020 году организациями бюджетной сферы, участвующими в реализации пилотного проекта ФСС РФ «прямые выплаты»;

Предоставление земельных участков под видом их перераспределения может быть расценено в качестве способа обхода закона;

Минтрудом России обобщена практика применения мер по предотвращению и урегулированию конфликта интересов и т.д. [9; 13].

Следует указать, что до вступления в силу вышеуказанного законодательства в 2019-2020 гг. существовали серьезные проблемы в рамках реализации форм МЧП в современной российской практике по целому ряду причин, в первую очередь - отсутствие юридического регулирования это предоставление муниципальных гарантий некоему частному хозяйствующему субъекту, а также создание совместно управляемых юридических лиц - эти нормы, несмотря на присутствие в федеральном законодательстве де-факто не работают. При этом, как минимум есть принципиально важная разница между МЧП и публично-частным партнерством - последнее является более широким, зонтичным понятием, определяющим вообще любое привлечение бизнеса к решению задач местной власти, в то время как конкретно МЧП - исключительно долгосрочное (не менее трех лет согласно российскому законодательству) системное взаимодействие представителей местной власти или органов местного самоуправления по решению масштабных задач в области доступа населения к разнообразным услугам, 
а также привлечению длительных инвестиций в экономику муниципальных субъектов в целом. На практике можно сказать, что организация 2-3 дневного фестиваля, приуроченного к какой-либо местнозначимой дате или событию - это пример публично-частного партнерства, а вот организация ремонта или строительства платной автодороги на муниципальной земле с последующей сдачей ее в концессию на 25 лет - это и есть пример хорошо сработавшего МЧП.

При этом, как уже было указано выше, далеко не все формы МЧП вообще осуществляются в России на практике, а из осуществленных проектов абсолютно большая часть принадлежит концессионным договорам (самая распространенная форма), инвестиционным соглашениям и капитальному строительству через конкретное инвестирование в бюджет, в то время как остальные формы взаимодействия либо не используются вообще (муниципальные гарантии и совместно управляемые юридические лица), либо используются весьма ограниченно, как правило - в конкретных, специфических условиях тех или иных регионов.

Еще одной глобальной, всероссийской проблемой, которая оказывает огромное влияние на процесс внедрения любых проектов МЧП, является специфика кадастрового учета в России, и реальное положение дел в государственных земельных и имущественных кадастрах в целом. На сегодняшний день в едином, государственном Кадастре недвижимого имущества отсутствует огромное количество объектов, разбросанных по всей России без исключения. Попадание таких земель либо объектов недвижимости в сферу применения любого договора МЧП провоцирует целый ряд проблем - от отсутствия сведений о проложенных коммуникациях, что критически важно для любых строительных или ремонтных работ, до отсутствия четких географических рамок территорий, которые могут быть использованы частным партнером. Все это в конечном итоге может привести к срыву соглашения о МЧП, причем как естественному, так и коррупционно-мотивированному, когда часть администрации, зная о наличии «подводных камней» в сфере соглашения, сознательно оказывает давление на частных партнеров, с целью получения собственной выгоды.

В целом же, по состоянию на конец 2017 календарного года в Российской Федерации на муниципальном уровне реализовывалось всего 1975 проектов в данном случае статус «реализующегося» присваивался проекту в том случае, если соответствующий юридически оформленный договор МЧП между государственной и частной сторонами был подписан и вступил в законную силу. В целом можно говорить о явной тенденции к росту интереса по отношению к возможности реализации МЧП, так как на конец 2013 года количество реально действующих проектов не превышало 300 [3. С. 68]. Очевидна тенденция увеличения проектов МЧП в современной России.

Однако объективная невозможность привлечения серьезных иностранных инвестиций малыми муниципалитетами Российской Федерации, об- 
условленная в том числе и внешнеполитической конфронтацией, а также политикой иностранных санкций, которые служат не столько экономическим, сколько политическим «пугалом» для любого иностранного инвестора. Представляется важным проанализировать совокупность методов, техник и инструментов, которые используют даже малые и слаборазвитые страны с целью привлечения инвестиций от собственного частного бизнеса. В этой связи наиболее репрезентативным и полезным для использования в России представляется опыт стран Европейского Союза, что обусловлено в том числе и развитой системой местного самоуправления в этих странах, одной из главных целей которой является развитие отстающих регионов, которое впоследствии обеспечивает развитие всего государства в целом. Это очень лаконично выражено в положении № 6 преамбулы Европейской Хартии самоуправления - «существование территориальных общностей с подлинными компетенциями делает государственное управление эффективным и в то же время обеспечивает участие граждан в управлении государством» [2].

В странах Европейского Союза на сегодняшний день принцип муниципально-частного партнерства (в английском языке для этого применяется термин «Public-private partnership» или его аббревиатуры - PРP, 3Р, Р3) используется для решения целого ряда весьма важных вопросов местного значения, начиная от традиционного благоустройства территории и организации местных праздников, заканчивая отраслями крайне важными для населения - это и энерго-, водо-, и тепло-снабжение, и содержание и организация местных дорог, и даже организация местного публичного транспорта.

Говоря в целом о странах ЕС, можно отметить первую принципиальную разницу в практических подходах к реализации МЧП - если в России в общем объеме договоров об МЧП безусловно лидирует транспортная отрасль (и как было сказано выше, существует ряд обоснованных претензий к реализации таких соглашений), то в ЕС сфера МЧП в первую очередь концентрируется на областях здравоохранения, а также образовательных услуг, но не транспортных концессий. Так например, в Федеративной Республике Германия по данным на конец 2019 года система здравоохранения представлена тремя практически равновеликими секторами - $31 \%$ учреждений является собственностью государства (с учетом как федеральной, так и собственности того или иного земельного правительства, что практически идентично системе распределения государственной собственности в России), 36\% учреждений принадлежат некоммерческому сектору - в первую очередь это церковно-приходские больницы, а также учреждения Красного Креста, и $31 \%$ медицинских учреждений являются частными [8]. При этом, еще в 1995 году только 4\% лечебных учреждений принадлежали частному сектору, и этот рост обусловлен во многом активным применениям механизма МЧП в области здравоохранения [10. С. 99-102]. 
Как правило, в случае если государственная клиника стабильно и в течении долгого периода времени показывала крайне низкие результаты с точки зрения ликвидности, и объем бюджетных дотаций на нее рос с каждым годом, то такое учреждение за символическую плату передавалось в управление (де-факто - в концессию) частному сектору, фактически - по договору об МЧП. Однако, в таком договоре прописывались четкие обязательства о необходимости обеспечивать в клинике полный объем медицинских услуг в рамках системы государственного медицинского страхования, а также прописывался определенный срок, в течении которого учреждение должно было выйти на уровень собственной финансовой ликвидности. В случае неисполнения всех этих обязательств, договор МЧП расторгался и, как правило, вскоре находился новый инвестор. Кроме явных преимуществ в области экономии государственного бюджета, такая система позволяла убрать или сократить до минимума риски пациента, обращающегося за лечением в рамках медицинского страхования, чаще всего такие пациенты вообще не интересовались принадлежностью больницы, поскольку с их точки зрения разницы или не было, или же она была минимальной.

В России, а также в большинстве стран СНГ, в связи с полным отсутствием такой практики, частные медицинские учреждения, как правило, создаются изначально в формате исключительного частного бизнеса, может вообще не оказывать услуг в формате системы обязательного медицинского страхования (или оказывать в минимальном формате), так как создается с полного его основания без какого-либо участия со стороны государства и, следовательно, никак к государственной системе здравоохранения не относится. Это в конечном итоге провоцирует, во-первых, социальную конфликтность, так как формирует «медицину для бедных» - ОМС, и «медицину для богатых» - систему частных клиник и полисов ДМС, разница в качестве предоставляемых услуг, между которыми все сильнее увеличивается разрыв по мере того, как муниципальные клиники, обеспечиваемые только хронически дефицитными государственными бюджетами, вынуждены все больше экономить как на качестве своих услуг, так и на зарплатах персонала.

В целом, по данным Европейского центра экспертизы (European Partnership Expert Center - EPEC), в странах Европейского Союза за период 2005-2017 годов в среднем за год осуществлялось более 100 инфраструктурных проектов на условиях партнерства государственных органов и частного бизнеса в той или иной сфере. При этом, среднегодовой объем проектов, созданных в результате такого партнерства в указанный период, составил около 20,3 млрд. евро. При этом, структура использования подобных совместных проектов год от года стабильна среди ЕС - непременным лидером является Великобритания, на втором месте также стабильно находится Франция, на третьем - Германия, а на четвертом и пятом, как правило, 
Нидерланды и Польша соответственно. На данный момент Польша - единственная из стран бывшего социалистического лагеря, активно перенявшая проектную методику совместного партнерства, и активно применяющая ее в собственных инфраструктурных проектах между частным бизнесом и институтами местного самоуправления [6. С. 59-65].

Количество методик и инструментов ЕС, направленных на расширение участия частного сектора в различных государственных экономических проектах любого уровня, на сегодняшний день только увеличивается. Так, например, Европейским парламентом была принят и утвержден программный документ под названием Cohesion Program Regulation (CPR), рассчитанный на период 2015-2030 г.г., ныне успешно действующий. Данная программа направлена на стандартизацию процесса экономического партнерства между государственными институтами и частным сектором, а также позволяет обращаться за со-финансированием самых масштабных проектов из единого бюджета ЕС. Такими проектами, согласно определению, прописанному в CPR, являются дороги общеевропейского значения, различные энергетические коммуникации (от энергосетей до нефте- и газопроводов) а также объекты телекоммуникации, поддерживающие и развивающие общеевропейское покрытие сети Интернет, телефонной и иных видов связи.

При этом, стоит особо отметить и главный принцип со-финансирования проектов, применяемых в большинстве случаев европейскими фондами, который выражается в определении «funding gap» (буквально с англ. «финансирование разрыва», в данном случае под разрывом понимается экономический термин «кассовый разрыв», описывающий ситуацию, когда участнику проекта нужно оплатить некоторые расходы на проект до того, как он получит гарантированную прибыль) [14. Р. 101]. В данном случае принцип «funding gap» используется для финансирования крупных инфраструктурных объектов до момента, когда они будут закончены или выйдут на плановую мощность, и тем самым смогут быть рентабельными самостоятельно, без необходимости как со стороны государственных органов, так и частного инвестора постоянно вкладывать в проект исключительно собственные средства. Стоит отметить, что подобный «funding gар» является очень частой проблемой в реализации проектов МЧП в России, но качественных инструментов его преодоления, кроме дополнительного кредитования, на данный момент найдено не было.

Также подобный принцип со-финансирования решает другую частую проблему функционирования МЧП, которая проявляется в российской повседневной практике - это проблема распределения ответственности и полномочий между двумя сторонами. При применении принципа софинансирования появляется равноудаленная третья сторона, которая может при необходимости взять на себя функции независимого арбитра по отношению к двум основным участникам процесса, что позволяет решать 
множество возникающих спорных ситуаций, которые в современной российской практике решаются либо административным давлением, либо преждевременным завершением проекта МЧП [4. С. 110-114]. Кроме того, при некоторых обстоятельствах, именно серьезная поддержка третьей независимой стороны в ряду случаев позволяет поддержать жизнеспособность проекта в случае если частный партнер финансово не может выполнять возложенные на него обязательства. Такой принцип позволяет как поддерживать проект до восстановления финансовой состоятельности частного партнера (если это объективно временное состояние), либо поддерживать проект в ситуации срочной замены и поиска другого частного партнера.

Таким образом, многообразие применения различных техник, инструментов и механизмов в процессе реализации методик государственно-частного и муниципально-частного партнерства, применяемого на сегодняшний день странами Европейского союза, представляется крайне актуальным для изучения и последующей адаптации с целью применения в российской повседневной экономической и политической практике развития МЧП.

Вместе с тем, Президент РФ В.В. Путин в своем Ежегодном Послании Федеральному Собранию РФ 15 января 2020 г. особо подчеркнул необходимость увеличения роли местного самоуправления в рамках нового качества государственного управления и публичной власти в современной России в целом: «Считаю необходимым закрепить в Конституции принципы единой системы публичной власти, выстроить эффективное взаимодействие между государственными и муниципальными органами. При этом полномочия и реальные возможности местного самоуправления - самого близкого к людям уровня власти - могут и должны быть расширены и укреплены [1]. Безусловно, расширение и укрепление реальных полномочий органов местного самоуправления, а также эффективное взаимодействие между органами государственной и муниципальной власти будут способствовать усилению государственно-частного и муниципально-частного партнерства в реализации масштабных проектов, позволят начать новый этап во взаимоотношениях муниципальной власти и органов местного самоуправления с частным бизнесом в современной России.

\section{БИБЛИОГРАФИЧЕСКИЙ СПИСОК:}

1. Ежегодное Послание Президента РФ В.В. Путина Федеральному Собранию РФ 15 января 2020 г. // http://kremlin.ru.

2. Европейская хартия местного самоуправления ETS № 122. Страсбург, 15 октября 1985 г. // http://base.garant.ru/2540485/

3. Есин B.B. Сферы применения муниципально-частного партнерства и государственно-муниципально-частного партнерства // Конституционное и муниципальное право. 2017. № 9. 
4. Жигляева А.В. Проблема неконтролируемого роста долга российских регионов и муниципальных образований // Вопросы науки РЭУ им. Г.В. Плеханова. 2017. № 15.

5. Кабанова И.Е. Муниципально-частное партнерство: специфика, правовое регулирование, примеры и проблемы реализации // Доклад о состоянии местного самоуправления в Российской Федерации: Изменение баланса интересов государственной власти и местного самоуправления / под ред. Е.С. Шугриной. М., 2017.

6. Криворотько Ю. Финансирование государственно-частного партнерства в странах Европейского Союза: новые подходы для стран ЕАЭС // Банкаускі веснік. 2017. № 4.

7. Липенков А.В. Исследование простоев маршрутных транспортных средств в ожидании дополнительных пассажиров на остановочных пунктах // Вестник Иркутского государственного технического университета. 2014. № 2.

8. Министерство здравоохранения ФРГ // https://www.bundesgesundheitsministerium.de.

9. Обзор изменений законодательства за период с 01 декабря 2019 года по 15 января 2020 года Центра местного самоуправления Института управления и регионального развития РАНХиГС при Президенте РФ // http://131fz. ranepa.ru/post $/ 1368$.

10. Панова T.B. Опыт развитых европейских стран в использовании форм и моделей ГЧП в здравоохранении // Экономика и управление народным хозяйством. 2015. № 10.

11. Устав городского округа «Город Улан-Удэ» (Приложение к решению Улан-Удэнского городского Совета депутатов от 25.04.2019 No 542-52) // https://ulan-ude-eg.ru/upload/iblock/e8f/Ustav-goroda.pdf.

12. Федеральный закон № 224-Ф3 от 13.07.2015 «О государственно-частном партнерстве, муниципально-частном партнерстве в Российской Федерации и внесении изменений в отдельные законодательные акты Российской Федерации»// http://www.consultant.ru/document/cons_doc_LAW_182660/

13. Федеральный закон от 27.12.2019 No 485-Ф3 «О внесении изменений в Федеральный закон» «О государственных и муниципальных унитарных предприятиях» и Федеральный закон «О защите конкуренции» // Обзор изменений законодательства за период с 01 декабря 2019 года по 15 января 2020 года Центра местного самоуправления Института управления и регионального развития РАНХиГС при Президенте РФ // http://131fz.ranepa.ru/ post $/ 1368$.

14. Rao P.K. Development finance. Heidelberg, Springer, 2003. 
S.L. SERGEYEVA

Candidate of Political Sciences,

associate professor of political science and political management of School of political researches

of Institute of social sciences of the Russian Presidential Academy of National Economy and Public Administration under the President of the Russian Federation,

Moscow, Russia

P.V. GAPONOV

Post-graduate student of political science and political management department, School of political researches of Institute of social sciences of the Russian Presidential Academy of National Economy and Public Administration under the President of the Russian Federation, Moscow, Russia

\title{
PRACTICE OF IMPLEMENTING PROJECTS BASED ON MUNICIPAL-PRIVATE PARTNERSHIP IN THE RUSSIAN FEDERATION AND THE EUROPEAN UNION: A COMPARATIVE ANALYSIS
}

\begin{abstract}
Process of development of the municipal-private partnerhip experienced its "rebirth" after 2015, when significant changes were made to the relevant Russian federal legislation. The article analyzes the key problems in the implementation of municipal-private partnership projects, which arose after the above changes. Legislative changes give the possibility to start a new level, in the relationship of municipal authorities and local governments with private business. However, it is necessary to recognize that the pace of development this kind of process in Russia, remains fairly modest, given the huge and constantly growing debt burden on municipalities. Taking into account the fact that the current international political situation does not allow Russian economy to hope for any substantial amount of foreign investment in the regional Russian economy, it is necessary to further improve the partnership mechanisms between state authorities and the private sector. Proceeding from this, it seems important to analyze the experience of the development of the PPP mechanisms in the format of the European Union, which has more historical development experience in this field. This article analyzes the key mechanisms that EU countries use for more effective interaction and the development of joint infrastructure and other socially significant projects, as well as the management principles on which such projects are organized. It seems that some of these tools, especially the co-financing methodology, the principle of "funding gap", that is, accounting and financing "cash gaps" as well as the
\end{abstract}


introduction of independent arbitration in the implementation of joint projects, are extremely relevant for should be carefully analyzed for the purpose of subsequent adaptation and introduction into Russian economic, legal and political practice.

Key words: municipal-private partnership, MPP, public-private partnership, PPP, local government, European Charter of Local Self-Government, Cohesion Program Regulation, public-private partnership, PPP, funding gap. 